\title{
Pengaruh Kualitas PelayananBarbershop Terhadap Kepuasan Konsumen Memilih Barbershop (Studi pada Konsumen Balaputra Barbershop Palembang)
}

\author{
Nenny Octarinie,S.E.,M.M \\ Dosen PNS Dpk Fakultas Ekonomi Universitas Palembang
}

\begin{abstract}
ABSTRAK
Penelitian ini bertujuan untuk mengetahui pengaruh kualitas pelayanan barbershop terhadap kepuasan konsumen memilih Balaputra Barbershop Palembang. Sampel pada penelitian ini berjumlah 100responden. Data yang digunakan adalah data primer yang dianalisis dengan menggunakan persamaan regresi linier bergandaa, uji hipotesis (uji $t$ dan uji f), serta koefisien determinasi $\left(R^{2}\right)$. Hasil penelitian diperoleh $Y=1,155+$ $0,261 X_{1}+0,280 X_{2}+0,334 X_{3}+0,217 X_{4}+0,321 X_{5}$. Konstanta sebesar 1,155 adalah kepuasan konsumensebelum dipengaruhi oleh variabel kualitas pelayanan. Hasil perhitungan menunjukkan nilai $R^{2}=0,514$. Hal ini berarti bahwa sebesar 51,4\% variasi naik turunnya kepuasan konsumen dipengaruhi variabel Kualitas Pelayanan . Sedangkan sisanya sebesar 49,6\% dipengaruhi oleh variabel lain yang tidak terdapat pada penelitian ini.
\end{abstract}

\section{Kata Kunci : Kualitas Pelayanan, Kepuasan Konsumen}

\section{PENDAHULUAN}

\subsection{Latar Belakang Masalah}

Kualitas pelayanan yang tinggi adalah salah satu kunci keberhasilan dalam persaingan bisnis, karena kualitas pelayanan yang bagus menunjukkan produktifitas dan kemampuan menghasilkan kepuasaan konsumen. Pada dasarnya pengertian kualitas pelayanan merupakan penilaian antara harapan dan kinerja yang dirasakan. (Yamit, 2001). Perusahaan akan sangat beruntung apabila dapat mengetahui apa yang diinginkan konsumen atas produknya. Hal tersebut merupakan informasi yang sangat berharga yang dapat digunakan untuk melakukan evaluasi terhadap perusahaannya. Selain itu juga berguna bagi perusahaan untuk memahami dan kemudian berusaha untuk memenuhi semua semua kenginan konsumen. Diharapkan juga pihak perusahaan dapat menentukan kebijkankebijakan dalam strategi memasarkan produknya dan untuk menghadapi para pesaingnya. Seiring pertumbuhan zaman dan meningkatnya taraf hidup masyarakat, maka gaya hidup masyarakat pun akan semakin berkembang. Hal ini membuat masyarakat semakin peduli dengan penampilan dan berlomba-lomba untuk memperbaiki penampilan mereka baik dari segi penampilan maupun gaya rambut yang mengikuti tren. Umumnya, hanya kaum perempuan yang dikenal suka menganti gaya rambut, namun sekarang kaum laki-laki pun juga peduli dengan gaya rambut. Dahulu, laki-laki hanya perlu ke tukang cukur dibawah pohon atau dipinggir jalan untuk memangkas rambut yang sering disebut dengan potong rambut Madura. Kini, tukang cukur dibawah pohon dan dipinggir jalan menjadi lebih modern dengan sebutan barbershop, namun dengan kualitas yang jauh lebih baik dari tukang cukur yang dipinggir jalan. Barbershop umumnya menampilkan nuansa maskulin yang kental, mulai dari sumber daya manusianya yang sangat ahli pada bidangnya dan mampu membuat konsumennya lebih percaya diri dengan diri mereka.

Balaputra

Barbershop merupakan salah satu penyedia jasa bisnis pangkas rambut terbaik di kota Palembang. Potensi bisnis ini jelas besar karena kebutuhan untuk memangkas rambut adalah kegiatan yang pasti akan 
dilakukan oleh setiap orang secara periodik. Dalam kondisi persaingan yang ketat, hal utama yang harus diprioritaskan oleh Balaputra Barbershop adalah kualitas pelayanan yang dapat memberikan kepuasan kepada konsumen. Kualitas pelayanan menjadi topik yang menarik untuk dikaji, dikarenakan kualitas pelayanan dapat menentukan kepuasaan konsumen atas produk yang ditawarkan, sehingga jaminan kualitas menjadi prioritas utama bagi perusahaan. Dengan semakin banyaknya barbershop yang menyediakan pelayanan yang sama seperti, Barberbox Barbershop, Big Daddy Barbershop, F1 Barbershop, tetapi Balaputra Barbershop menjadi salah satu pilihan remaja, dibandingkan dengan barbershop lainnya. Banyak remaja di kota Palembang memilih Balaputra Barbershop karena harga yang terjangkau tetapi dengan kualitas yang tidak kalah saing dengan barbershop lainya.

Usaha pangkas rambut merupakan usaha yang bergerak di salah satu bidang produk jasa murni, artinya produk yang ditawarkan hampir semua berupa jasa dan pelayanan. Kualitas layanan adalah ukuran seberapa bagus tingkat layanan yang diberikan mampu sesuai dengan ekspetasi pelanggan (Tjiptono,2009:14). Dengan kualitas pelayanan yang optimal akan membuat usaha pangkas rambut lambat laun akan berkembang dengan sendirinya. Untuk menarik perhatian pelanggan/konsumen dalam membuat keputusan untuk menggunakan jasa yang di tawarkan oleh barber shop, maka dari itu Barber shop harus pula memberikan layanan yang berkualitas kepada pelanggan. Layanan yang berkulitas dibutuhkan dalam Barber Shop untuk memenangkan pasar dalam dunia persaingan.

Kualitas jasa juga sering didefinisikan sebagai pemenuhan dan keinginan pelanggan serta ketepatan penyampaian jasa dalam rangka memenuhi harapan pelanggan. Sebab kualitas jasa yang baik bisa membuat orang percaya akan kualitas seorang kapster di Barbershop. Maka dari itu kapster di Balaputra Barbershop terus meningkatkan kualitas pelayanan/jasa agar pelanggan mendapatkan hasil yang memuaskan.

Berdasarkan latar belakang yang telah disampaikan tersebut, maka penulis tertarik untuk melakukan penelitian dengan menggunakan judul :

Pengaruh Kualitas Pelayanan Barbershop Terhadap Kepuasan Konsumen Memilih Barbershop (Studi pada Konsumen Balaputra Barbershop Palembang).

\subsection{Perumusan Masalah}

Berdasarkan uraian latar belakan diatas maka dapat dirumuskan masalah sebagai berikut

a. Bagaimana Pengaruh Kualitas Pelayanan yang terdiri daritangible, reliability, responsiveness, assurance, empathy secara simultan dan parsial

terhadap Kepuasan konsumen Balaputra Barbershop?

b. Variabel manakah diantara tangible, reliability, responsiveness, assurance, empathy yang memiliki pengaruh paling dominan terhadap Kepuasan konsumen Balaputra Barbershop ?.

\subsection{Tujuan Penelitian}

Sesuaidenganperumusanmasala hdiatas,makatujuandaripenelitian iniadalah

1. Untuk menganalisis pengaruh variabel yaitu tangible, reliability, responsiveness, assurance dan emphaty parsial dan simultan terhadap Kepuasan konsumen Balaputra Barbershop

2. Untuk menganalisis pengaruh yang paling dominan diantara masingmasing variabel yaitu tangible, reability, responsiveness, assurance dan emphaty terhadap Kepuasan konsumen Balaputra Barbershop. 


\section{TINJAUAN PUSTAKA \\ 2.1. Landasan Teori \\ 2.1.1 Pengertian Kualitas \\ Pelayanan}

Ada beberapa ahli yang mengemukakan pendapat tentang definisi kualitas, yaitu :

Menurut Nursya'baini (2006 :78), Kualitas adalah kecocokan penggunaan produk (fitness for use) untuk memenuhi kebutuhan dan kepuasan pelanggan. Kecocokan penggunaan suatu produk adalah apabila produk mempunyai daya tahan penggunaan yang lama, meningkatkan citra atau status konsumen yang memakainya, tidak mudah rusak, adanya jaminan kualitas dan sesuai etika bila digunakan. Khusus untuk jasa diperlukan pelayanan kepada pelanggan yang ramah, sopan serta jujur sehingga dapat menyenangkan atau memuaskan pelanggan.

Menurut David Garvin (2007:98), Kualitas adalah suatu kondisi dinamis yang berhubungan dengan produk, manusia/tenaga kerja, proses dan tugas, serta lingkungan yang memenuhi atau melebihi harapan pelanggan atau konsumen. Selera atau harapan konsumen pada suatu produk selalu berubah sehingga kualitas produk juga harus berubah atau disesuaikan. Dengan perubahan kualitas produk tersebut, diperlukan perubahan atau peningkatan keterampilan tenaga kerja. Kualitas pelayanan sangat dipengaruhi oleh harapan konsumen. Harapan konsumen dapat bervariasi dari konsumen satu dengan konsumen lain walaupun pelayanan yang diberikan konsisten. Kualitas mungkin dapat dilihat sebagai suatu kelemahan ketika konsumen mempunyai harapan yang terlalu tinggi, walaupun dengan suatu pelayanan yang baik.

$$
\text { Menurut }
$$

A.Parasuraman (2006:110), Kualitas Pelayanan adalah keberhasilan perusahaan dalam memberikan layanan yang bermutu kepada para pelanggannya, pencapaian pangsa pasar yang tinggi, serta peningkatan profit perusahaan tersebut sangat ditentukan oleh pendekatan yang digunakan. Konsekuensi atas pendekatan kualitas pelayanan suatu produk memiliki esensi penting bagi strategi perusahaan untuk mempertahankan diri dan mencapai kesuksesan dalam menghadapi persaingan. Salah satu pendekatan kualitas pelayanan yang banyak dijadikan acuan dalam riset pemasaran adalah model Service Quality (Serqual) yang dikembangkan terhadap enam sektor jasa, yaitu reparasi, peralatan rumah tangga, kartu kredit, asuransi, sambungan telepon jarak jauh, perbankan ritel dan pialang sekuritas.

\subsubsection{Dimensi Kualitas}

Dimensi kualitas dapat dijadikan dasar bagi pelaku bisnis untuk mengetahui apakah ada kesenjangan (gap) atau perbedaan antara harapan pelanggan dan kenyataan yang mereka terima. Harapan pelanggan sama dengan keinginan pelanggan yang ditentukan oleh informasi yang mereka terima dari mulut ke mulut, kebutuhan pribadi, pengalaman masa lalu dan komunikasi eksternal melalui iklan dan promosi. Jika kesenjangan antara harapan dan kenyataan cukup besar, hal ini menunjukkan bahwa perusahaan tidak mengetahui apa yang diinginkan oleh pelanggannya.

Menurut Zeithaml, Berry dan Parasuraman, telah melakukan berbagai penelitian terhadap beberapa jenis jasa, dan berhasil mengidentifikasi lima dimensi karakteristik yang digunakan oleh para pelanggan dalam mengevaluasi kualitas pelayanan. Kelima dimensi karakteristik kualitas pelayanan tersebut adalah :

1) Reliability (kehandalan), yaitu kemampuan dalam memberikan pelayanan dengan segera dan memuaskan serta sesuai dengan telah yang dijanjikan. (daya tangkap), yaitu keinginan para staf untuk membantu para pelanggan dan memberikan pelayanan dengan tanggap.

2) Assurance (jaminan), yaitu mencakup kemampuan, kesopanan dan sifat dapat 
dipercaya yang dimiliki para staf, bebas dari bahaya, resiko ataupun keragu-raguan.

3) Empathy, yaitu meliputi kemudahan dalam melakukan hubungan, komunikasi yang baik, dan perhatian dengan tulus terhadap kebutuhan pelanggan.

4) Tangibles (bukti langsung), yaitu meliputi fasilitas fisik, perlengkapan, pegawai, dan sarana komunikasi.

\subsubsection{Pengertian Kepuasan Konsumen}

Kepuasan bisa diartikan sebagai upaya pemenuhan sesuatu atau membuat sesuatu memadai ( Tjiptono dan Chandra, 2009 : 195 ). Sedangkan Kotler ( 2005:61 ) mendefinisikan kepuasan sebagai perasaan senang atau kecewa seseorang yang dialami setelah membandingkan antara persepsi kinerja atau hasil suatu produk dengan harapanharapannya. Dari definisi-definisi tersebut di atas dapat disimpulkan, yaitu adanya perbandingan antara harapan dan kinerja/hasil yang dirasakan pelanggan. Harapan pelanggan dibentuk dan didasarkan oleh beberapa faktor, di antaranya pengalaman berbelanja di masa lampau, opini teman dan kerabat, serta informasi dan janji-janji perusahaan dan para pesaing.

Perusahaan yang baik adalah yang mampu memberikan kepuasan terhadap konsumennya. Konsumen yang puas dapat melakukan berbagai tindakan terhadap perusahaan tersebut dengan memberikan rekomendasi kepada orang lain ataupun menggunakan poduk atau jasa secara berulang dan terus menerus. Menurut Kotler (Tjiptono, 2005:148) dalam mengukur kepuasan pelanggan terdapat empat metode, yaitu

1) Sistem keluhan dan saran, artinya setiap perusahaan yang berorientasi pada pelanggan perlu memberikan kesempatan seluas-luasnya bagi para pelanggannya untuk menyampaikan saran, pendapat, dan keluhan mereka.
2) Survei kepuasan pelanggan, artinya kepuasan pelanggan dilakukan dengan menggunakan metode survei, baik melalui pos, telepon, maupun wawancara pribadi. Dengan melalui survei, perusahaan akan memperoleh tanggapan dan umpan balik secara langsung dari pelanggan sekaligus juga memberikan tanda positif bahwa perusahaan menaruh perhatian terhadap para pelanggannya.

3) Ghost Shopping, artinya metode ini dilaksanakan dengan cara memperkerjakan beberapa orang (Ghost shopper) untuk berperan atau bersikap sebagai pelanggan/pembeli potensial produk perusahaan dan pesaing. Kemudian Ghost sopper menyampaikan temuan-temuan mengenai kekuatan dan kelemahan produk perusahaan dan pesaing berdasarkan pengalaman mereka dalam pembelian produk-produk tersebut.

4) Lost customer analysis, artinya perusahaan menghubungi para pelanggannya yang telah berhenti membeli atau yang telah beralih pemasok dan diharapkan diperoleh informasi penyebab terjadinya hal tersebut.

\subsubsection{Metode Servqual}

Metode Servqual banyak digunakan untuk mengukur kualitas layanan. Boleh dikatakan metode ini mudah dicerna dan tidak perlu dilakukan analisis statistik yang rumit untuk menentukan skor kualitas pelayanan. Servqual sendiri berasal dari kata Service Quality yang artinya Kualitas Pelayanan. Metode ini didasarkan pada "Gap Model" yang dikembangkan oleh Parasuraman, et $(1988,1991,1993,1994)$ (Purnama, 2006, hal 155).

Dalam metode servqual, skor dilihat dari besarnya gap antara persepsi dan harapan pelanggan. Teori servqual 
berasumsi bahwa kepuasan pelanggan tercipta karena harapan pelanggan terpenuhi oleh kenyataan pelayanan yang didapat pelanggan. Skor dalam servqual kemudian melihat apakah terjadi gap yang positif, gap nol, atau gap negatif antara harapan dan kenyataan. Gap positif menunjukkan bahwa kualitas pelayanan melebihi harapan pelanggan. Gap nol menunjukkan kualitas pelayanan sama dengan harapan pelanggan. Gap negatif terjadi bila kualitas pelayanan jauh dari harapan pelanggan. Semakin besar nilai negatif tentu menunjukkan rendahnya kualitas yang diberikan. Sebaliknya, semakin positif maka menunjukkan tingginya kualitas pelayanan.

Metode servqual bahkan bisa mengukur mulai gap antara persepsi dan harapan pelanggan, gap antara pelanggan dengan frontliners, dan gap antara frontliners dengan menajemen perusahaan. Dengan demikian proses perbaikan pelayanan bisa dilakukan mulai dari level paling bawah sampai paling atas.

\subsubsection{Gap (Kesenjangan)}

A Parasuraman, L.L. berry dan V.A. Zeithaml dan Berry, (2008:17) mengembangkan model kualitas jasa pelayanan dan berupaya mengenali kesenjangan(gaps) pelayanan yang terjadi dan berupaya mencari jalan keluar untuk mengurangi atau bahkan menghilangkan kesenjangan pelayanan tersebut.

Secara umum, kesenjangan pelayanan dapat dibedakan ke dalam dua kelompok, yaitu: Kesenjangan yang muncul dari dalam perusahaan (company gaps). Kesenjangan ini dapat menghambat kemampuan perusahaan untuk memberikan pelayanan berkualitas.

1. Kesenjangan yang muncul dari dalam perusahaan dapat dibedakan ke dalam empat jenis kesenjangan, yaitu :

a) Kesenjangan 1: tidak mengetahui harapan konsumen akan pelayanan b) Kesenjangan 2 : tidak memiliki desain dan standar pelayanan yang tepat

c) Kesenjangan 3 : tidak memberikan pelayanan berdasar standar pelayanan

d) Kesenjangan 4 : tidak memberikan pelayanan sesuai yang dijanjikan

2. Kesenjangan yang muncul dari luar perusahaan.

a) Kesenjangan 1 ditimbulkan karena ketidaksesuaian antara persepsi yang dibuat oleh manajemen tentang harapan-harapan konsumen.

b) Kesenjangan 2 timbul karena ketidak mampuan manajemen dalam merumuskan tingkat sasaran kualitas pelayanan untuk memenuhipersepsi harapan tamu, dan ketidak mampuannya untukmenterjemahkan ke dalam spesifikasi pekerjaan guna merealisasikantingkat sasaran kualitas pelayanan tersebut.

c) Kesenjangan 3 disebabkan karena ketidaksesuaian pelayanan yangdiberikan dengan para konsumen, dengan spesifikasi pelayanan yang telahditentukan oleh manajemen

d) Kesenjangan 4 disebabkan karena perbedaan antara pelayanan yangtelah dijanjikan oleh pihak manajemen. Dengan yang diterima olehkonsumen, perbedaan ini diakibatkan kurangnya informasi internal dan eksternal

e) Kesenjangan 5 disebabkan karena akumulasi dari kesenjangan kesenjangan yang lain (1 s.d 4) yaitu berakhir pada terjadinya ketidak sesuaian antara harapan konsumen, dengan kenyataaan yang diterima oleh para konsumen.

\subsection{Penelitian terdahulu}

1. Analisis Kualitas Pelayanan Terhadap Kepuasan Konsumen REAL7 Barbershop Yogyakarta . Skripsi Oleh Werdyan Indra Ardiansa,UII 2018. Berdasarkan hasil penelitian seperti yang telah diuraikan pada bab sebelumnya dapat ditarik beberapa kesimpulan yaitu, tingkat harapan konsumen terhadap 
kualitas pelayanan pada Real7 BarbershopYogyakarta adalah sebesar 3,78 dan nilai tersebut dalam kondisi konsumen mempunyai harapan yang baik terhadap kualitas pelayanan Real7 Barbershop Yogyakarta sedangkan tingkat kinerja konsumen kualitas pelayanan pada Real7 Barbershop Yogyakarta adalah sebesar 4,15 dan nilai tersebut dalam kondisi konsumen menilai baik mengenai kualitas pelayanan Real7 Barbershop Yogyakarta.

2. Pengaruh Kualitas Pelayanan dan Suasana Barbershop Terhadap Keputusan Memilih Barbershop (Studi pada konsumen Raja Cukur Barbershop Candi Panggung Malang) . Skripsi Oleh Ahmad
Imam Fakhruddin, Universitas Muhammadiyah Malang 2018 Hasil penelitian ini di peroleh dari perhitungan SPSS berdasarkan korelasi untuk variabel Kualitas Jasa (X1) terhadap Keputusan Pembelian Konsumen (Y) sebesar 0.787 yang kuat. Dan varibelKualitas Jasa (X1) signifikan dengan variabel Keputusan Pembelian Konsumen (Y) karena nilai sig 0,00 yang lebih kecil maka Ho di tolak. Jadi dalam hal ini pelaku usaha bisa meningkatkan Kualitas Jasanya agar menjadi lebik baik lagi karena variabel sudah signifikan. Karena setidaknya variabel Kualitas Jasa sudah mencapai tujuan yang di inginkan pemilikusaha pangkat rambut.

\subsection{Kerangka Fikir}

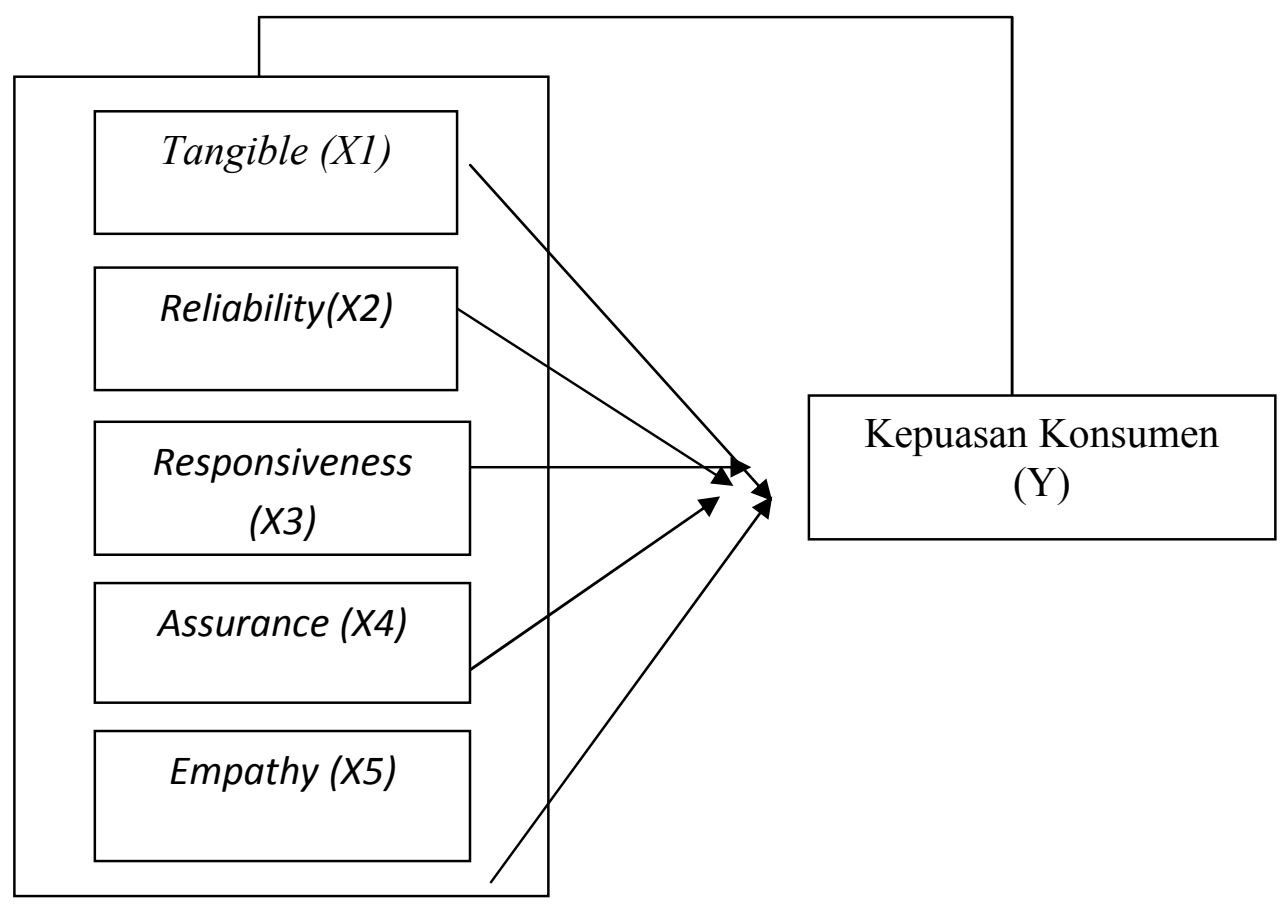

\subsection{Hipotesis}

1. Terdapat pengaruh secara simultan antara kualitas pelayanan yang terdiri dari Tangible (Bukti Fisik), Reliability (kehandalan), Responsiveness (daya tanggap), Assurance (jaminan) Empathy (empati) terhadapKepuasan konsumen Balaputra Barbershop

2. Terdapat pengaruh yang dominan kualitas pelayanan yang terdiri dari Tangible (Bukti Fisik) Reliability (kehandalan), Responsiveness (daya tanggap), Assurance (jaminan) Empathy (empati) terhadap Kepuasan konsumen Balaputra Barbershop 


\section{METODOLOGI \\ PENELITIAN}

\subsection{Objek Penelitian}

Penelitian ini mengambil objek penelitian pada Balaputra Barbershop Palembang yang berlokasi di Jalan Parameswara No.1178A Bukit Baru Kecamatan Ilir Barat I Kota Palembang, Sumatera Selatan

\section{2 . Ruang Lingkup Penelitian}

Penelitian ini membahas mengenai kualitas pelayanan yang terdiri dari Tangible atau bukti langsung, Reliability atau kehandalan, Responsiveness atau daya tanggap, Assurance atau jaminan, Empaty atau Empati serta pengaruhnya terhadap Kepuasan konsumen Balaputra Barbershop.

\subsection{Desain Penelitian}

Pada penelitain kali ini, penulis menggunakan penelitian korelasional yaitu suatu penelitian yang menghubungkan satu atau lebih variabel bebas dengan satu variabel terikat tanpa ada upaya untuk mempengaruhi variabel tersebut. Penelitian korelasional mendasarkan diri pada logika deduktif, yaitu dimulai dengan menggunakan sebuah teori sebagai dasar dan diakhiri dengan analisis data hasil

\subsection{Jenida dan Sumber Data \\ 3.4.1 Jenis Data}

a. Data Primer

Data primer merupakan sumber data penelitian yang diperoleh secara langsung dari sumber asli (tidak melalui perantara). Data primer yang digunakan dalam penelitian ini adalah hasil pengisian kuesioner oleh responden, yaitu konsumen yang pernah menggunakan jasa pada Balaputra Barbershop.

\section{b. Data Sekunder}

Data sekunder adalah data yang diperoleh secara tidak langsung, baik berupa keterangan maupun literatur yang ada hubungannya dengan penelitian. Data sekunder dalam penelitian ini antara lain berbagai studi kepustakaan yaitu pengumpulan data yang diperoleh melalui buku-buku dan karya ilmiah yang berkaitan dengan penelitian.

\subsubsection{Metode Pengumpulan Data}

Alat dalam penelitian ini adalah respon atau tanggapan responden mengenai kualitas pelayanan serta variabel yang memiliki pengaruh terhadap kualitas pelayanan yang diberikan oleh Balaputra Barbershopdengan cara membagikan kuesioner. Bentuk pertanyaan yang diajukan adalah pertanyaan tertutup berdasarkan dimensi kualitas pelayanan dan kepuasan konsumen pada Balaputra Barbershop

\subsection{POPULASI DAN SAMPEL}

\subsubsection{Populasi}

Populasi ialah gabungan dari seluruh elemen yang berbentuk peristiwa, hal, atau orang yang memilki karakteristik yang serupa yang menjadi pusat semesta penelitian (Ibnu Widiyanto, 2008 : 223). Populasi dalam penelitian ini adalah semua pengguna jasa di Balaputra Barbershop Palembang

\subsubsection{Sampel}

Sampel adalah bagian dari jumlah dan karakteristik yang dimiliki oleh populasi tersebut. Dalam penelitian ini tidak seluruh anggota populasi diambil, melainkan hanya sebagian dari populasi. Karena jumlah pelanggan yang pernah menggunakan jasa pada Balaputra Barbershop Palembang tidak diketahui pasti, maka menggunakan rumus menurut Widiyanto (2008), yaitu

Widiyanto (2008) mengatakan bahwa jumlah sampel yang digunakan adalah sebanyak 100 responden dengan penentuan sampel. Jumlah responden sebanyak 100 orang tersebut dianggap sudah representative karena sudah lebih besar dari batas minimal sampel. Metode pengambilan sampel dilakukan dengan menggunakan metode non probably sampling, dengan teknik Convenience sampling yaitu pengambilan sampel yang tidak 
memberi peluang atau kesempatan sama bagi setiap unsur atau anggota populasi untuk dipilih menjadi sampel, karena hanya yang sudah pernah menggunakan jasa pada Balaputra Barbershop Palembang yang menjadi sampel dalam penelitian.

\subsection{DEFINISI OPERASIONAL DAN PENGUKURAN VARIABEL}

Tabel 2

Definisi Operasional Variabel

\begin{tabular}{|c|c|c|c|}
\hline Variabel & $\begin{array}{c}\text { Definisi } \\
\text { Operasional } \\
\text { Variabel }\end{array}$ & Indikator & Parameter \\
\hline $\begin{array}{l}\text { Kualitas } \\
\text { Pelayanan } \\
\text { (X) }\end{array}$ & $\begin{array}{l}\text { Keadaan } \\
\text { dinamis yang } \\
\text { berkaitan erat } \\
\text { dengan produk, } \\
\text { jasa, sumber } \\
\text { daya manusia, } \\
\text { serta proses } \\
\text { dan lingkungan } \\
\text { yang } \\
\text { setidaknya } \\
\text { dapat } \\
\text { memenuhi atau } \\
\text { malah dapat } \\
\text { melebihi } \\
\text { kualitas } \\
\text { pelayanan yang } \\
\text { diharapkan. }\end{array}$ & $\begin{array}{ll}\text { 1. } & \text { Bukti Fisik (X1) } \\
\text { 2. } & \text { Kepercayaan (X2) } \\
\text { 3. } & \text { Daya Tanggap (X3) } \\
\text { 4. } & \text { Jaminan (X4) } \\
\text { 5. } & \text { Empati (X5) }\end{array}$ & $\begin{array}{l}\text { 1. Bukti Fisik (X1), terdiri dari } \\
\text { a. Ruang tunggu yang nyaman } \\
\text { b. Lokasi Strategis } \\
\text { c. Kebersihan yang baik } \\
\text { 2. Kepercayaan (X2) } \\
\text { a. Kemudahan memilih model rambut } \\
\text { b. Ketepatan dalam mencukur } \\
\text { c. Pelayanan yang memuaskan } \\
\text { 3. Daya Tanggap (X3) } \\
\text { a. Kecepatan menanggapi keluhan } \\
\text { b. Tanggapan terhadap pertanyaan } \\
\text { c. Ponsumen } \\
\text { 4. Jaminan (X4) } \\
\text { a. Profesional } \\
\text { b. Dapat dipercaya } \\
\text { c. Ramah dan Sopan } \\
\text { 5. Empati (X5) } \\
\text { a. Perhatian terhadap konsumen } \\
\text { b. Perlakuan yang sama kepada setiap } \\
\text { c. Mensumen } \\
\text { kemahami kebutuhan dan }\end{array}$ \\
\hline $\begin{array}{c}\text { Kepuasan } \\
\text { Konsumen } \\
\text { (Y) }\end{array}$ & $\begin{array}{l}\text { Kepuasan } \\
\text { konsumen } \\
\text { didefinisikan } \\
\text { sebagai } \\
\text { perasaaan } \\
\text { senang atau } \\
\text { kecewa } \\
\text { seseorang dari } \\
\text { membandingka } \\
\text { n kinerja } \\
\text { produk yang } \\
\text { dirasakan } \\
\text { dalam han dan } \\
\text { hubungan } \\
\text { harapannya } \\
\text { (Kotler2001,21 } \\
\text { ). }\end{array}$ & $\begin{array}{ll}\text { 2. } & \text { Minat Berkunjung } \\
\text { Kembali }\end{array}$ & $\begin{array}{l}\text { a. Karyawan memberikan pelayanan yang } \\
\text { baik. } \\
\text { b. Pelayanan yang diberikan sesuai dengan } \\
\text { harapan. } \\
\text { c. Fasilitas dan ruang tunggu yang } \\
\text { disediakan sangat memadai } \\
\text { a. Konsumen berminat berkunjung } \\
\text { kembali karena pelayanan memuaskan. } \\
\text { b. Konsumen berminat berkunjung } \\
\text { kembali karena produk yang dipakai } \\
\text { memberikan hasil garapan yang } \\
\text { memuaskan. }\end{array}$ \\
\hline
\end{tabular}


3. Kesediaan merekomendasikan a. Konsumen bersedia menyarankan teman atau kerabat untuk menggunakan jasa pada Balaputra Barbershop Palembang karena pelayanan yang memuaskan.

b. Konsumen menyarankan teman atau kerabat untuk menggunakan jasa pada Balaputra Barbershop Palembang karena produk dan fasilitas penunjang yang disediakan memadai.

\subsection{TEKNIK ANALISIS}

3.7.1 Pengujian Kualitas Data

- UjiValiditas

Uji validitas digunakan untuk mengukur sah atau tidaknya suatu kuesioner.Suatu kuesioner dikatakan sah jika pertanyaan pada kuesioner mampu mengungkapkan sesuatu yang akan diukur oleh kuesioner tersebut.Uji validitas dilakukan dengan membandingkan nilai $r$ hitung (untuk setiap butir dapat dilihat pada kolom correcteditem-total correlations) dengan $r$ tabel untuk degreeof freedom $(d f)=\mathrm{n}-\mathrm{k}$, dalam hal ini $\mathrm{n}$ adalah jumlah sampel dan $\mathrm{k}$ adalah jumlah item.Jika $r$ hitung $>\quad r$ tabel,maka pertanyaan tersebut dikatakan valid

\subsubsection{Uji Reliabilitas}

Uji Reliabilitas merupakan alat untuk mengukur suatu kuisioner yang merupakan indikator dari variabel atau konstruk. Suatu kuisioner dikatakan reliable atau handal jika jawaban seseorang terhadap pertanyaan konsisten dari waktu ke waktu. SPSS memberikan fasilitas untuk mengukur reliabilitas dengan uji statistik Cronbach Alpha ( $\alpha$ ). Suatu variabel dikatakan reliabel jika memberikan nila $\alpha>0,60$ (Nunnally,1967 dalam Ghozali,2015)

\subsubsection{Analisis Regresi Linier Berganda \\ Analisis regresi berganda} digunakan untuk mengetahui ada tidaknyapengaruh antara kualitas pelayanan (tangibles, reliability, responsiveness, assurancedanempathy) terhadap kepuasan konsumen Balaputra Barbershop. Model hubungan nilai pelanggan dengan variabel-variabel tersebutdapatdisusundalamfungsiat aupersamaansebagaiberikut

$$
\begin{aligned}
& Y=b_{1} X_{1}+b_{2} X_{2}+b_{3} X_{3}+b 4 X_{4}+b_{5} X_{5} \\
& \text { Dimana } \\
& \text { Y =KepuasanKonsumen } \\
& \text { b1 =KoefisienregresivariabelX1(tangible) } \\
& \text { b2 =KoefisienregresivariabelX2(reliability) } \\
& \text { b3 =KoefisienregresivariabelX3(responsiveness) } \\
& \text { b4 =KoefisienregresivariabelX4(assurance) } \\
& \text { b5 =KoefisienregresivariabelX5(empathy) } \\
& \text { X1 =Bukti fisik(Tangible) } \\
& \mathrm{X}_{2}=\text { Kehandalan(Reliability) } \\
& \text { X3 =Dayatanggap }(\text { Responsiveness })
\end{aligned}
$$




$$
\begin{array}{ll}
\mathrm{X} 4 & =\mathrm{Jaminan}(\text { Assurance }) \\
\mathrm{X} 5 & =\text { Empati/kepedulian(Empathy) }
\end{array}
$$

\subsubsection{Uji Hipotesis}

\section{- Uji Hipotesis Pengaruh Simultan(UjiF)}

Dalam penelitianini, hipotesisyangdigunakanadalah:

Ho : Variabel-variabelbebasyaitutangible, reliability, responsiveness, assurance dan emphaty tidak mempunyai pengaruh yang signifikan secara bersama-samaterhadap variabelterikatnyayaituloyalitas pelanggan.

Ha : Variabel-variabelbebasyaitutangible, reliability, responsiveness, assurancedan emphatymempunyaipengaruhyangsignifikansecara bersamasamaterhadapvariabelterikatnyayaituloyalitas pelanggan.

Dasar pengambilan keputusannya adalah dengan menggunakan angka proba bilitas signifikansi, yaitu:

- Apabila probabilitas signifikansi $>0.05$, maka Ho diterima dan Ha ditolak.

- Apabila probabilitas signifikansi < 0.05, maka Ho ditolak dan Ha diterima.

\section{- Uji Hipotesis Pengaruh Parsial(Ujit)}

Hipotesis yang digunakan dalam pengujian ini adalah

Ho: Variabel-variabel bebas (tangible, reliability, responsiveness, assurancedan emphaty) tidak mempunyai pengaruh yang signifikan terhadap variabel terikat (loyalitas pelanggan).

Ha: Variabel-variabel bebas (tangible, reliability, responsiveness, assurance dan emphaty) mempunyai pengaruh yang signifikan terhadap variabel terikat (loyalitas pelanggan).

Dasar pengambilan keputusan adalah dengan menggunakan angka probabilita ssignifikansi,yaitu:

- Apabila angka probabilitas signifikani $>0.05$, maka Ho diterima dan Ha ditolak.

- Apa bila angka probabilitas signifikansi < 0.05, maka Ho ditolak dan Ha diterima.

\section{- Koofisien Determinasi}

Koefisien determinasi $\left(\mathrm{R}^{2}\right)$ dimaksudkan untuk mengetahui tingkat ketepatan paling baik dalam analisa regresi dimana hal yang ditunjukan oleh besarnya koefisien determinasi $\left(\mathrm{R}^{2}\right)$ antara 0 (nol) dan I (satu). Kooefsien determinasi $\left(\mathrm{R}^{2}\right)$ nol variabelin dependen sama sekali tidak berpengaruh terhadap variabel dependen .Apabila koefisien determinasi semakin mendekati satu, maka dapat dikatakan bahwa variabel independen berpengaruh terhadap variabel dependen` 


\section{HASIL PENELITIAN DAN PEMBAHASAN}

\subsection{Hasil Penelitian}

\subsubsection{Deskripsi Responden}

Responden dalam penelitian ini adalah Konsumen Balaputra Barbershop Palembang yang pernah berkunjung minimal $2 x$ ke barbershop ini. Adapun jumlah konsumen yang dipilih sebagai responden sebanyak 100 orang dengan identitas sebagai berikut : Usia, Jenis Kelamin, Pekerjaan

\section{- Jenis Kelamin}

Untuk mengetahui jumlah pelanggan melalui jenis kelamin laki-laki dan perempuan, dapat dilihat pada tabel 4.1 dibawah ini

Tabel 4.1.

Distribusi Responden berdasarkan Jenis Kelamin

\begin{tabular}{|c|c|c|}
\hline Jenis Kelamin & Frekuensi & Persentase \\
\hline Laki-laki & $\mathbf{1 0 0}$ & $\mathbf{1 0 0 \%}$ \\
\hline Perempuan & $\mathbf{0}$ & $\mathbf{0 \%}$ \\
\hline Total & $\mathbf{1 0 0}$ & $\mathbf{1 0 0 \%}$ \\
\hline
\end{tabular}

Sumber : data primer diolah 2020

Berdasarkan tabel diatas dapat diketahui bahwa jumlah responden sebanyak 100 orang terdiri dari $100 \%$ adalah laki-laki dan tidak ada konsumen perempuan.

Tabel 4.2.

Distribusi Responden berdasarkan Usia

\begin{tabular}{|c|c|c|}
\hline Usia & Frekuensi & Persentase \\
\hline$<\mathbf{3 0}$ tahun & $\mathbf{5 7}$ & $\mathbf{5 7} \%$ \\
\hline $\mathbf{3 1 - 4 0}$ tahun & $\mathbf{2 9}$ & $\mathbf{2 9} \%$ \\
\hline $\mathbf{4 1 - 5 0}$ tahun & $\mathbf{9}$ & $\mathbf{9 \%}$ \\
\hline$>\mathbf{5 0}$ tahun & $\mathbf{5}$ & $\mathbf{5 \%}$ \\
\hline Total & $\mathbf{1 0 0}$ & $\mathbf{1 0 0 \%}$ \\
\hline
\end{tabular}

Sumber : data primer diolah 2020

Berdasarkan tabel 4.2 diatas dapat dilihat bahwa usia responden sangat variatif. Responden dengan usia $<30$ tahun menempati persentase tertinggi yaitu sebesar 57\% diikuti responden dengan umur 31-40 tahun. Terlihat bahwa pengguna jasa barbershop ini mayoritas adalah anak-anak muda yang lebih mengedepankan mode dan gaya hidup.

Tabel 4.3.

Distribusi Responden berdasarkan Pekerjaan

\begin{tabular}{|c|c|c|}
\hline Unit Kerja & Frekuensi & Persentase \\
\hline Pelajar & 31 & $31 \%$ \\
\hline Mahasiswa & 29 & $29 \%$ \\
\hline Karyawan/Pegawai & 40 & $40 \%$ \\
\hline Total & 100 & $\mathbf{1 0 0 \%}$ \\
\hline
\end{tabular}

Sumber : data primer diolah 2020

Berdasarkan tabel diatas dapat diketahui bahwa jumlah responden terdiri dari berbagai kalangan pekerjaan. Mayoritas merupakan karyawan dan pegawai baik itu swasta ataupun negeri sebesar $40 \%$ serta responden yang merupakan 
pelajar sebesar 31 orang atau $31 \%$ dan terakhir merupakan mahasiwa yaitu sebesar 29 orang atau 29\%. Tabel ini pun menggambarkan betapa banyak konsumen Balaputra Barbershop merupakan kalangan muda.

\subsubsection{Analisis Data}

Analisis deskriptif bertujuan untuk memperjelas gambaran terhadap variabel-variabel penelitian. Variabel kualitas pelayanan menggunakan lima indikator, yaitu bukti fisik, keandalan, daya tanggap, jaminan dan kepedulian

\section{- Variabel Kualitas Pelayanan}

1) Variabel Bukti Fisik (X1)

Indikator bukti fisik di kembangkan menjadi 3 (tiga) butir pertanyaan.Respon para konsumen terhadap jasa yang diberikan oleh Baaputra Barbershop Palembang ditampilkan pada tabel di bawah ini :

Tabel 4.4

Balaputra Barbershop Palembang memiliki ruang tunggu yang nyaman

\begin{tabular}{|c|c|c|}
\hline Jawaban Responden & Frekuensi & Persentase \\
\hline Sangat Setuju & 77 & $\mathbf{7 7 \%}$ \\
\hline Setuju & $\mathbf{2 3}$ & $\mathbf{2 3 \%}$ \\
\hline Netral & -- & -- \\
\hline Tidak Setuju & -- & -- \\
\hline Sangat Tidak Setuju & -- & -- \\
\hline Total & $\mathbf{1 0 0}$ & $\mathbf{1 0 0 \%}$ \\
\hline
\end{tabular}

Sumber : data primer diolah 2020

Dari tabel 4.4 diatas sebagian besar responden menyatakan Sangat Setuju bahwa Balaputra Barbershop memiliki ruang tunggu yang nyaman. Hal ini terlihat dari 100 responden sebanyak 77\% menyatakan Sangat Setuju, kemudian 23\% menyatakan Setuju.

Ruang tunggu merupakan salah satu fasilitas yang diberikan oleh Balaputra Barbershop agar konsumen mereka merasa nyaman. Ruang tunggu mereka dilengkapi dengan sofa dan pendingin ruangan serta ada beberapa bahan bacaan yang dapat digunakan oleh konsumen sehingga mereka tidak merasa bosan pada saat menunggu antrian.

Tabel 4.5

Balaputra Barbershop Palembang memiliki kemudahan tempat / lokasi untuk di cari oleh konsumen

\begin{tabular}{|c|c|c|}
\hline Jawaban Responden & Frekuensi & Persentase \\
\hline Sangat Setuju & 13 & $13 \%$ \\
\hline Setuju & 87 & $87 \%$ \\
\hline Netral & -- & -- \\
\hline Tidak Setuju & -- & -- \\
\hline Sangat Tidak Setuju & -- & -- \\
\hline Total & $\mathbf{1 0 0}$ & $\mathbf{1 0 0 \%}$ \\
\hline
\end{tabular}

Sumber : data primer diolah 2020 
Dari tabel 4.5 diatas responden menyatakan Setuju bahwa Balaputra Barbershop memiliki lokasi yang strategis sehingga mudah untuk ditemukan oleh konsumen. Hal ini terlihat dari 100 responden sebanyak $87 \%$ menyatakan sangat Setuju dan sisanya 13\% menyatakan Sangat Setuju.

Tabel 4.6

Balaputra Barbershop Palembang memiliki kebersihan yang baik

\begin{tabular}{|c|c|c|}
\hline Jawaban Responden & Frekuensi & Persentase \\
\hline Sangat Setuju & 88 & $88 \%$ \\
\hline Setuju & 12 & $12 \%$ \\
\hline Netral & -- & -- \\
\hline Tidak Setuju & -- & -- \\
\hline Sangat Tidak Setuju & -- & -- \\
\hline Total & $\mathbf{1 0 0}$ & $\mathbf{1 0 0 \%}$ \\
\hline
\end{tabular}

Sumber : data primer diolah 2020

Dari tabel 4.6 diatas responden menyatakan Sangat Setuju bahwa Balaputra Barbershop Palembang selalu menjaga kebersihan pada area pemangkasan rambut mereka . Dengan begitu, secara tidak langsung memberikan kepuasan dan daya tarik tersendiri bagi para konsumen untuk datang kembali ke Balaputra Barbershop ini. Hal ini terlihat dari sebagian besar responden yaitu sebanyak $88 \%$ menyatakan sangat setuju dan sisanya sebanyak $12 \%$ menyatakan setuju.

Selain ruang tunggu yang nyaman dan lokasi yang strategis, bukti fisik berikutnya yang harus dijaga oleh Balaputra Barbershop adalah kebersihan baik itu didalam ataupun diluar ruangan mereka. Kebersihan merupakan salah satu aspek fisik yang mudah terlihat oleh konsumen secara langsung.

2) Variabel Reliability (X2)

Tabel 4.7

Karyawan Balaputra Barbershop Palembang memberikan kemudahan dalam memilih model rambut

\begin{tabular}{|c|c|c|}
\hline Jawaban Responden & Frekuensi & Persentase \\
\hline Sangat Setuju & 67 & $42 \%$ \\
\hline Setuju & 32 & $56 \%$ \\
\hline Netral & 1 & $2 \%$ \\
\hline Tidak Setuju & -- & -- \\
\hline Sangat Tidak Setuju & -- & -- \\
\hline Total & $\mathbf{1 0 0}$ & $\mathbf{1 0 0 \%}$ \\
\hline
\end{tabular}

Sumber : data primer diolah 2020

Dari tabel 4.7 diatas sebagian besar responden menyatakan setuju bahwa karyawan Balaputra Barbershop memberikan kemudahan/keleluasaan dalah hal pemilihan model rambut. Hal ini terlihat dari sebagian besar responden yaitu sebanyak 67\% menyatakan Sangat setuju dan sebanyak 32\% menyatakan Setuju. Namun terdapat pula konsumen yang menyatakan Netral walau hanya 1 orang saja. 
Tabel 4.8

Karyawan Balaputra Barbershop Palembang memberikan Ketepatan dalam mencukur

\begin{tabular}{|c|c|c|}
\hline Jawaban Responden & Frekuensi & Persentase \\
\hline Sangat Setuju & 19 & $19 \%$ \\
\hline Setuju & 80 & $80 \%$ \\
\hline Netral & -- & -- \\
\hline Tidak Setuju & 1 & $1 \%$ \\
\hline Sangat Tidak Setuju & -- & -- \\
\hline Total & $\mathbf{1 0 0}$ & $\mathbf{1 0 0 \%}$ \\
\hline
\end{tabular}

Sumber : data primer diolah 2020

Dari tabel 4.8 diatas sebagian besar responden menyatakan Setuju bahwa Karyawan Balaputra Barbershop Palembang memberikan Ketepatan dalam mencukur. Hal ini dibuktikan dari sebagian besar responden yaitu sebanyak $80 \%$ menyatakan Setuju dan sisanya sebanyak 19\% menyatakan SangatSetuju.

Tabel 4.9

Karyawan Balaputra Barbershop Palembang memberikan pelayanan yang memuaskan

\begin{tabular}{|c|c|c|}
\hline Jawaban Responden & Frekuensi & Persentase \\
\hline Sangat Setuju & 21 & $21 \%$ \\
\hline Setuju & 79 & $79 \%$ \\
\hline Netral & -- & -- \\
\hline Tidak Setuju & -- & -- \\
\hline Sangat Tidak Setuju & -- & -- \\
\hline Total & $\mathbf{1 0 0}$ & $\mathbf{1 0 0 \%}$ \\
\hline
\end{tabular}

Sumber : data primer diolah 2020

Dari tabel 4.9 diatas responden sebagian besar responden menyatakan bahwa Karyawan Balaputra Barbershop Palembang memberikan pelayanan yang memuaskan. Hal ini terlihat dari $79 \%$ responden menyatakan Setuju dan $21 \%$ menyatakan Sangat setuju.

3) Variabel Responsiveness (X3)

Tabel 4.10

Karyawan Balaputra Barbershop Palembang menanggulangi keluhan konsumen dengan cepat dan tepat

\begin{tabular}{|c|c|c|}
\hline Jawaban Responden & Frekuensi & Persentase \\
\hline Sangat Setuju & 46 & $46 \%$ \\
\hline Setuju & 54 & $54 \%$ \\
\hline Netral & -- & -- \\
\hline Tidak Setuju & -- & -- \\
\hline Sangat Tidak Setuju & -- & -- \\
\hline Total & $\mathbf{1 0 0}$ & $\mathbf{1 0 0 \%}$ \\
\hline
\end{tabular}

Sumber : data primer diolah 2020 
Dari tabel 4.10 diatas responden sebagian besar responden menyatakan bahwa Karyawan Balaputra Barbershop Palembang menanggulangi keluhan konsumen dengan cepat dan tepatterlihat dari 54\% responden menyatakan Setuju dan $46 \%$ menyatakan sangat setuju.

Tabel 4.11

Karyawan Balaputra Barbershop Palembang bersedia menanggapi setiap pertanyaan konsumen

\begin{tabular}{|c|c|c|}
\hline Jawaban Responden & Frekuensi & Persentase \\
\hline Sangat Setuju & 18 & $18 \%$ \\
\hline Setuju & 82 & $82 \%$ \\
\hline Netral & -- & -- \\
\hline Tidak Setuju & -- & -- \\
\hline Sangat Tidak Setuju & -- & -- \\
\hline Total & $\mathbf{1 0 0}$ & $\mathbf{1 0 0 \%}$ \\
\hline
\end{tabular}

Sumber : data primer diolah 2020

Dari tabel 4.11 diatas responden menyatakan bahwa Karyawan Balaputra Barbershop Palembang bersedia menanggapi setiap pertanyaan konsumenterlihat dari $82 \%$ responden menyatakan Setuju dan $18 \%$ menyatakan sangat setuju.

Tabel 4.12

Karyawan Balaputra Barbershop cepat dan tepat dalam memberikan informasi dan solusi yang dibutuhkan konsumen

\begin{tabular}{|c|c|c|}
\hline Jawaban Responden & Frekuensi & Persentase \\
\hline Sangat Setuju & 51 & $51 \%$ \\
\hline Setuju & 49 & $49 \%$ \\
\hline Netral & -- & -- \\
\hline Tidak Setuju & -- & -- \\
\hline Sangat Tidak Setuju & -- & -- \\
\hline Total & $\mathbf{1 0 0}$ & $\mathbf{1 0 0 \%}$ \\
\hline
\end{tabular}

Sumber : data primer diolah 2020

Dari tabel 4.12 diatas responden menyatakan bahwa Karyawan Balaputra Barbershop cepat dan tepat dalam memberikan informasi dan solusi yang dibutuhkan konsumenterlihat dari 51\% responden menyatakan sangat setuju dan $49 \%$ menyatakan setuju.

4) Variabel Assurance (X4)

Tabel 4.13

Karyawan Balaputra Barbershop Palembang professional

\begin{tabular}{|c|c|c|}
\hline Jawaban Responden & Frekuensi & Persentase \\
\hline Sangat Setuju & 23 & $33 \%$ \\
\hline Setuju & 76 & $76 \%$ \\
\hline Netral & 1 & $1 \%$ \\
\hline Tidak Setuju & -- & -- \\
\hline Sangat Tidak Setuju & -- & -- \\
\hline Total & $\mathbf{1 0 0}$ & $\mathbf{1 0 0 \%}$ \\
\hline
\end{tabular}

Sumber : data primer diolah 2020 
Dari tabel 4.13 diatas responden menyatakan bahwa Karyawan Balaputra Barbershop Palembang professionalterlihat dari 76\% responden menyatakan setuju dan $23 \%$ menyatakan sangat setuju namun ada pula responden yang menyatakan netral walau hanya $1 \%$ saja.

Tabel 4.14

Karyawan Balaputra Barbershop Palembang dapat dipercaya

\begin{tabular}{|c|c|c|}
\hline Jawaban Responden & Frekuensi & Persentase \\
\hline Sangat Setuju & 32 & $32 \%$ \\
\hline Setuju & 68 & $68 \%$ \\
\hline Netral & -- & -- \\
\hline Tidak Setuju & -- & -- \\
\hline Sangat Tidak Setuju & -- & -- \\
\hline Total & $\mathbf{1 0 0}$ & $\mathbf{1 0 0 \%}$ \\
\hline
\end{tabular}

Sumber : data primer diolah 2020

Dari tabel 4.14 diatas responden menyatakan bahwa Karyawan Balaputra Barbershop Palembang dapat dipercayaterlihat dari 68\% responden menyatakan setuju dan $32 \%$ menyatakan sangat setuju.

Tabel 4.15

Memberikan pelayanan yang ramah dan sopan terhadap konsumen

\begin{tabular}{|c|c|c|}
\hline Jawaban Responden & Frekuensi & Persentase \\
\hline Sangat Setuju & 49 & $49 \%$ \\
\hline Setuju & 51 & $51 \%$ \\
\hline Netral & -- & -- \\
\hline Tidak Setuju & -- & -- \\
\hline Sangat Tidak Setuju & -- & -- \\
\hline Total & $\mathbf{1 0 0}$ & $\mathbf{1 0 0 \%}$ \\
\hline
\end{tabular}

Sumber : data primer diolah 2020

Dari tabel 4.15 diatas responden menyatakan bahwa Karyawan Balaputra Barbershop Palembang telah memberikan pelayanan yang ramah dan sopan terhadap konsumen. Hal ini terlihat dari 51\% responden menyatakan Setuju dan $49 \%$ menyatakan Sangat Setuju.

\section{5) Variabel Emphaty (X5)}

Tabel 4.16

Karyawan Balaputra Barbershop Palembang memberikan perhatian kepada konsumen

\begin{tabular}{|c|c|c|}
\hline Jawaban Responden & Frekuensi & Persentase \\
\hline Sangat Setuju & 25 & $25 \%$ \\
\hline Setuju & 72 & $72 \%$ \\
\hline Netral & 1 & $1 \%$ \\
\hline Tidak Setuju & 2 & $2 \%$ \\
\hline Sangat Tidak Setuju & -- & -- \\
\hline Total & $\mathbf{1 0 0}$ & $\mathbf{1 0 0 \%}$ \\
\hline
\end{tabular}

Sumber : data primer diolah 2020 
Dari tabel 4.16 diatas terlihat bahwa jawaban responden sangat beragam. Hal ini menyangkut Karyawan Balaputra Barbershop Palembang memberikan perhatian kepada konsumen. Dari pernyataan tersebut terlihat bahwa konsumen yang menyatakan setuju hanya $72 \%$ kemudian yang menyatakan sangat setuju sebanyak $25 \%$ dan terdapat responden yang menyatakan sikap netralnya sebanyak $1 \%$ dan bahkan ada responden yang menyatakan sikap tidak setuju sebanyak 2 orang saja.

Tabel 4.17

Karyawan Balaputra Barbershop Palembang memberikan pelayanan dan komunikasi yang sama kepada semua konsumen tanpa terkecuali

\begin{tabular}{|c|c|c|}
\hline Jawaban Responden & Frekuensi & Persentase \\
\hline Sangat Setuju & 48 & $48 \%$ \\
\hline Setuju & 52 & $52 \%$ \\
\hline Netral & -- & -- \\
\hline Tidak Setuju & -- & -- \\
\hline Sangat Tidak Setuju & -- & -- \\
\hline Total & $\mathbf{1 0 0}$ & $\mathbf{1 0 0 \%}$ \\
\hline
\end{tabular}

Sumber : data primer diolah 2020

Dari tabel 4.17 diatas responden menyatakan bahwa Karyawan Balaputra Barbershop Palembang memberikan pelayanan dan komunikasi yang sama kepada semua konsumen tanpa terkecualiterlihat dari 52\% responden menyatakan setuju dan $48 \%$ menyatakan sangat setuju.

Tabel 4.18

Karyawan Balaputra Barbershop Palembang berusaha mengerti keinginan dan kebutuhan konsumen

\begin{tabular}{|c|c|c|}
\hline Jawaban Responden & Frekuensi & Persentase \\
\hline Sangat Setuju & 63 & $63 \%$ \\
\hline Setuju & 37 & $37 \%$ \\
\hline Netral & -- & -- \\
\hline Tidak Setuju & -- & -- \\
\hline Sangat Tidak Setuju & -- & -- \\
\hline Total & $\mathbf{1 0 0}$ & $\mathbf{1 0 0 \%}$ \\
\hline
\end{tabular}

Sumber : data primer diolah 2020

Dari tabel 4.18 diatas responden menyatakan bahwa Karyawan Balaputra Barbershop Palembang berusaha mengerti keinginan dan kebutuhan konsumenterlihat dari 55\% responden menyatakan Sangat Setuju dan 37\% menyatakan Setuju.

\section{A. Variabel Kepuasan Konsumen}

Indikator loyalitas pelanggan di kembangkan menjadi 7 (tujuh) butir pertanyaan.Adapun pernyataan-pernyataan responden yang mencerminkan tingkat Kepuasan Konsumen terhadap elayanan Balaputra Barbershop Palembang dapat dilihat pada tabel di bawah ini : 
Tabel 4.19

Karyawan memberikan pelayanan yang baik.

\begin{tabular}{|c|c|c|}
\hline Jawaban Responden & Frekuensi & Persentase \\
\hline Sangat Setuju & 12 & $12 \%$ \\
\hline Setuju & 81 & $81 \%$ \\
\hline Netral & 7 & $7 \%$ \\
\hline Tidak Setuju & -- & -- \\
\hline Sangat Tidak Setuju & -- & -- \\
\hline Total & $\mathbf{1 0 0}$ & $\mathbf{1 0 0 \%}$ \\
\hline
\end{tabular}

Sumber : data primer diolah 2020

Dari tabel 4.19 diatas responden menyatakan Karyawan Balaputra Barbershop memberikan pelayanan yang baik terlihat dari $81 \%$ responden menyatakan setuju dan $12 \%$ menyatakan sangat setuju namun terdapat pula konsumen yang menyatakan sikap netral pernyataan diatas sebanyak 7\% saja.

Tabel 4.20

Pelayanan yang diberikan sesuai dengan harapan.

\begin{tabular}{|c|c|c|}
\hline Jawaban Responden & Frekuensi & Persentase \\
\hline Sangat Setuju & 13 & $13 \%$ \\
\hline Setuju & 87 & $87 \%$ \\
\hline Netral & -- & -- \\
\hline Tidak Setuju & -- & -- \\
\hline Sangat Tidak Setuju & -- & -- \\
\hline Total & $\mathbf{1 0 0}$ & $\mathbf{1 0 0 \%}$ \\
\hline
\end{tabular}

Sumber : data primer diolah 2020

Dari tabel 4.20 diatas responden menyatakan Pelayanan oleh Balaputra Barbershop Palembang yang diberikan sesuai dengan harapankonsumen . Hal ini terlihat dari $87 \%$ responden menyatakan setuju dan $13 \%$ menyatakan sangat setuju .

Tabel 4.21

Fasilitas dan ruang tunggu yang disediakan sangat memadai

\begin{tabular}{|c|c|c|}
\hline Jawaban Responden & Frekuensi & Persentase \\
\hline Sangat Setuju & 39 & $39 \%$ \\
\hline Setuju & 61 & $61 \%$ \\
\hline Netral & -- & -- \\
\hline Tidak Setuju & -- & -- \\
\hline Sangat Tidak Setuju & -- & -- \\
\hline Total & $\mathbf{1 0 0}$ & $\mathbf{1 0 0 \%}$ \\
\hline
\end{tabular}

Sumber : data primer diolah 2020

Dari tabel 4.21 diatas responden menyatakan bahwa Balaputra Barbershop telah menyediakan Fasilitas dan ruang tunggu yang disediakan sangat memadai terlihat bahwa sebagian besar responden yaitu sebanyak $61 \%$ menyatakan setuju dan 39\% menyatakan sangat setuju. 
Tabel 4.22

Saya berminat berkunjung kembali karena pelayanan memuaskan.

\begin{tabular}{|c|c|c|}
\hline Jawaban Responden & Frekuensi & Persentase \\
\hline Sangat Setuju & 44 & $28 \%$ \\
\hline Setuju & 56 & $72 \%$ \\
\hline Netral & -- & -- \\
\hline Tidak Setuju & -- & -- \\
\hline Sangat Tidak Setuju & -- & -- \\
\hline Total & $\mathbf{1 0 0}$ & $\mathbf{1 0 0 \%}$ \\
\hline
\end{tabular}

Sumber : data primer diolah 2020

Dari tabel 4.22 diatas responden menyatakan bahwa mereka berminat berkunjung kembali karena pelayanan memuaskan.Terlihat dari 56\% responden menyatakan Setuju dan 44\% menyatakan sangat setuju.

Tabel 4.23

Saya berminat berkunjung kembali karena hasil potongan rambut memuaskan dan sesuai keinginan Saya

\begin{tabular}{|c|c|c|}
\hline Jawaban Responden & Frekuensi & Persentase \\
\hline Sangat Setuju & 63 & $63 \%$ \\
\hline Setuju & 37 & $37 \%$ \\
\hline Netral & -- & -- \\
\hline Tidak Setuju & -- & -- \\
\hline Sangat Tidak Setuju & -- & -- \\
\hline Total & $\mathbf{1 0 0}$ & $\mathbf{1 0 0 \%}$ \\
\hline
\end{tabular}

Sumber : data primer diolah 2020

Dari tabel 4.22 diatas responden menyatakan bahwa mereka berminat berkunjung kembali karena hasil potongan rambut memuaskan dan sesuai keinginan mereka. Hal ini terlihat dari $63 \%$ responden menyatakan Sangat setuju dan 38\% menyatakan sangat Setuju.

Tabel 4.24

Saya menyarankan teman atau kerabat untuk menggunakan jasa pada Balaputra Barbershop Palembang karena pelayanan yang memuaskan

\begin{tabular}{|c|c|c|}
\hline Jawaban Responden & Frekuensi & Persentase \\
\hline Sangat Setuju & 83 & $28 \%$ \\
\hline Setuju & 17 & $72 \%$ \\
\hline Netral & -- & -- \\
\hline Tidak Setuju & -- & -- \\
\hline Sangat Tidak Setuju & -- & -- \\
\hline Total & $\mathbf{1 0 0}$ & $\mathbf{1 0 0 \%}$ \\
\hline
\end{tabular}

Sumber : data primer diolah 2020

Dari tabel 4.24 diatas responden menyatakan bahwa mereka akan menyarankan teman atau kerabat untuk menggunakan jasa pada Balaputra Barbershop Palembang karena pelayanan yang memuaskan.Hal ini terlihat dari 
$83 \%$ responden menyatakan Sangat Setuju dan 17\% menyatakan Setuju.

Tabel 4.25

Saya menyarankan teman atau kerabat untuk menggunakan jasa pada Balaputra Barbershop Palembang karena produk dan fasilitas penunjang yang disediakan memadai

\begin{tabular}{|c|c|c|}
\hline Jawaban Responden & Frekuensi & Persentase \\
\hline Sangat Setuju & 62 & $28 \%$ \\
\hline Setuju & 38 & $72 \%$ \\
\hline Netral & -- & -- \\
\hline Tidak Setuju & -- & -- \\
\hline Sangat Tidak Setuju & -- & -- \\
\hline Total & $\mathbf{1 0 0}$ & $\mathbf{1 0 0 \%}$ \\
\hline
\end{tabular}

Sumber : data primer diolah 2020

Dari tabel 4.22 diatas responden menyatakan bahwa mereka akan menyarankan teman atau kerabat untuk menggunakan jasa pada Balaputra Barbershop Palembang karena produk dan fasilitas penunjang yang disediakan memadai. Hal ini terlihat dari $62 \%$ responden menyatakanSangat Setuju dan 38\% menyatakan Setuju.

\subsubsection{Pengujian Kualitas Data}

\section{A. Uji Validitas}

Validitas atau kesahihan menunjukkan sejauh mana suatu alat ukur mampu mengukur apa yang ingin diukur. Uji validitas dihitung dengan membandingkan nilai $r$ hitung (correlated item-total correlation) dengan nilai $r$ tabel, jika $r$ hitung $>$ dari $\mathrm{r}$ tabel (pada taraf signifikansi 5\%), maka butir pernyataan dinyatakan valid begitu juga berlaku sebaliknya.

Tabel4.26

HasilPengujianValiditas

\begin{tabular}{|c|c|c|c|c|}
\hline No & Indikator & rhitung & rtahel & Keterangan \\
\hline \multirow[t]{4}{*}{1} & Tangibles & & & \\
\hline & - Indikator1 & 0.356 & 0,197 & Valid \\
\hline & - Indikator2 & 0.367 & 0,197 & Valid \\
\hline & - Indikator3 & 0.476 & 0,197 & Valid \\
\hline \multirow[t]{4}{*}{2} & Reliability & & & \\
\hline & - Indikator1 & 0.441 & 0,197 & Valid \\
\hline & - Indikator2 & 0.354 & 0,197 & Valid \\
\hline & - Indikator3 & 0.412 & 0,196 & Valid \\
\hline \multirow[t]{4}{*}{3} & Responsiveness & & & \\
\hline & - Indikator1 & 0.287 & 0,197 & Valid \\
\hline & - Indikator2 & 0.409 & 0,197 & Valid \\
\hline & - Indikator3 & 0.246 & 0,197 & Valid \\
\hline \multirow[t]{3}{*}{4} & Assurance & & & \\
\hline & - Indikator1 & 0.340 & $\begin{array}{l}0,197 \\
0107\end{array}$ & Valid \\
\hline & - Indikator3 & 0.381 & 0,197 & Valid \\
\hline
\end{tabular}




\begin{tabular}{|c|c|c|c|c|}
\hline 5 & \begin{tabular}{|ll}
\multicolumn{2}{l}{ Emphaty } \\
- & Indikator1 \\
- & Indikator2 \\
- & Indikator3
\end{tabular} & $\begin{array}{l}0.442 \\
0.478 \\
0.572\end{array}$ & $\begin{array}{l}0,197 \\
0,197 \\
0,197\end{array}$ & $\begin{array}{l}\text { Valid } \\
\text { Valid } \\
\text { Valid }\end{array}$ \\
\hline 6 & 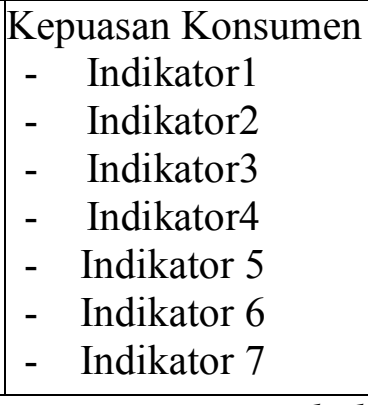 & $\begin{array}{l}0.595 \\
0.778 \\
0.681 \\
0.742 \\
0.780 \\
0.554 \\
0.659\end{array}$ & $\begin{array}{l}0,197 \\
0,197 \\
0,197 \\
0,197 \\
0,197 \\
0,197 \\
0,197\end{array}$ & $\begin{array}{l}\text { Valid } \\
\text { Valid } \\
\text { Valid } \\
\text { Valid } \\
\text { Valid } \\
\text { Valid } \\
\text { Valid }\end{array}$ \\
\hline
\end{tabular}

\section{Sumber:Dataprimeryang diolah2020}

Tabel4.26 menunjukkan bahwa semua indikator yang digunakan untuk mengukur variabel-variabel yang digunakan dalam penelitian ini mempunyai nilai korelasi yang lebih besar dari 0,196.Dari hasil tersebut menunjukkan bahwa semua indikator tersebu tadalah valid.

\section{B. Uji Reliabilitas}

Pengujian reliabilitas dalam penelitian ini adalah dengan menggunakan rumus Cronbach Alpha. Hasil pengujian reliabilitas untuk masing-masing variabel yang diringkas pada tabel 4.27 berikut ini:

Tabel 4.27

HasilPengujianReliabilitas

\begin{tabular}{|l|c|c|}
\hline \multicolumn{1}{|c|}{ Variabel } & Alpha & Keterangan \\
\hline Tangibles & 0,661 & Reliabel \\
\hline Reliability & 0,725 & Reliabel \\
\hline Responsiveness & 0,665 & Reliabel \\
\hline Assurance & 0,770 & Reliabel \\
\hline Empathy & 0,613 & Reliabel \\
\hline Kepuasan Konsumen & 0,775 & Reliabel \\
\hline
\end{tabular}

Hasil uji reliabilitas tersebut menunjukkan bahwa semua variabel mempunya ikoefisien Alpha yang cukup besar yaitu diatas 0,6 sehingga dapat dikatakan semua konsep pengukur masing-masing variabel dari kuesioner adalah reliabel yang berarti bahwa kuesioner yang digunakan dalam penelitian ini merupakan kuesioner yang handal.

\subsection{AnalisisRegresiLinierBerganda}

Regresi linier berganda digunakan dalam penelitian ini dengan tujuan untuk membuktikan hipotesis mengenai adanya pengaruh variabel Kualitas Pelayanan yang terdiri dari Tangibles, Reliability, Responsiveness, Empathy, Assurance secara parsial maupun secara bersama-sama terhadap Kepuasan Konsumen (Y). Perhitungan statistik dalam analisis regresi linier berganda yang digunakan dalam penelitian ini adalah dengan menggunakan bantuan program komputer SPSS forWindows versi 22.0. Hasil pengolahan data dengan menggunakan program SPSS selengkapnya ada pada lampiran dan selanjutnya diringkas sebagai berikut : 
Tabel 4.28

HasilAnalisisRegresiLinierBerganda

\begin{tabular}{|c|c|c|c|c|c|}
\hline Model & \multicolumn{2}{|c|}{$\begin{array}{l}\text { Unstandardized } \\
\text { Coefficients } \\
\text { B } \mid \text { Std.Error }\end{array}$} & $\begin{array}{l}\text { Standardized } \\
\text { Coefficients } \\
\text { Beta }\end{array}$ & \multirow{2}{*}{$\begin{array}{c}\mathrm{t} \\
\mathrm{t} \\
1.965\end{array}$} & \multirow{2}{*}{$\begin{array}{l}\text { sig } \\
\text { Sig. } \\
.001\end{array}$} \\
\hline $1 \quad$ (Constant) & 1.155 & .558 & & & \\
\hline Tangibles & $.261 \mid$ & $.127 \mid$ & .175 & 2.055 & .000 \\
\hline Reliability & .280 & .080 & .187 & 2.249 & .052 \\
\hline Responsiveness & 334 & .092 & 304 & 2.114 . & 043 \\
\hline Assurance & & & & & \\
\hline Empathy & .211 & .075 & .143 & 2.256 & .000 \\
\hline & .321 & .113 & .231 & 3.195 & .027 \\
\hline
\end{tabular}

a. DependentVariable:Kepuasan Konsumen (Y).

Adapun model persamaan regresi yang dapat dituliskan dari hasil tersebut dalam bentuk persamaan regresi sebagai berikut :

$$
\begin{aligned}
\mathrm{Y}= & 1,155+0,261 \mathrm{X}_{1}+0,280 \mathrm{X}_{2}+ \\
& 0,334 \mathrm{X}_{3}+0,217 \mathrm{X}_{4}+0,321 \mathrm{X}_{5}
\end{aligned}
$$

Persamaan regresi tersebut dapat dijelaskan sebagai berikut :

a. Konstanta sebesar 1,155 artinya jika Kualitas Pelayanan yang terdiri dari Tangibles/ Bukti Fisik (X1), Reliability/Kehandalan (X2), Responsiveness/ Daya Tanggap (X3), Assurance/Jaminan (X4) dan Empathy/Kepedulian (X5) nilainya adalah nol maka Kepuasan Konsumen (Y) nilainya adalah 1,155 .

b. KoefisienregresivariabelTangibles/ Bukti Fisik(X 1) sebesar 0,261 artinya jika variabel independen lainnya nilainya tetap dan nilai Tangibles/buktifisik mengalami kenaikan 1\% maka nilai Kepuasan Konsumen akan meningkat sebesar 26,1\%.

c. KoefisienregresivariabelR e li a b i lity/kehandalan(X2) sebesar 0,280 artinya jika variabel independen lainnya nilainya tetap dan nilai Reliability/kehandalan (X2) mengalami kenaikan 1\% maka nilai Loyalitas Pelanggan akan meningkat sebesar 28\%.

d. KoefisienregresivariabelR e s p o n siveness / Daya Tanggap (X 3 ) sebesar 0,334 artinya jika variabel independen lainnya nilainya tetap dan nilai Responsiveness/daya tanggap (X3) mengalami kenaikan 1\% maka nilai Kepuasan Konsumen meningkat sebesar 33, $4 \%$.

e. KoefisienregresivariabelA s s u ra n c e/Jaminan (X 4) sebesar 0,217 artinya jika variabel independen lainnya nilainya tetap dan niai Assurance/ Jaminan (X4) mengalami kenaikan 1\% maka nilai Kepuasan Konsumen akan meningkat sebesar 21,7\%.

f. KoefisienregresivariabelE $\mathrm{m} p$ at $\mathrm{h}$ y/Kepedulian(X 5 ) sebesar 0,321 artinya jika variabel independen lainnya nilainya tetap 
dan niai Empathy/Kepedulian (X5) mengalami kenaikan 1\% maka nilai Kepuasan Konsumen akan meningkat sebesar 32,1\%.

\subsection{Pengujian Hipotesis}

\subsubsection{Uji t (Pengujian hipotesis secara parsial)}

1. Variabel Tangibles / Bukti Fisik Hasil pengujian diperoleh nilai $\mathrm{t}$ untuk variabel tampilan fisik (tangible) menunjukkan nilai $\mathrm{t}=2,055$ dengan nilai signifikansi sebesar $0,000<0,05$. Dengan nilai signifikansi dibawah 0,05 tersebut menunjukkan bahwa bukti fisik (tangible) memiliki pengaruh yang signifikan terhadap Kepuasan Konsumen. $\mathrm{Ha}$ lini berarti Hipotesis1diterima.Arah diterima. Arah koefisien regresi positif berarti bahwa bukti fisik memiliki pengaruh positif yang signifikan terhadap Kepuasan Konsumen.Semakin besa rbukti fisik yang diberikan oleh Balaputra Barbershop Palembang akan semakin tinggi pula Kepuasan konsumen,sebalikny asemakin rendahbukti fisik yang diberikan perusahaan semakin rendah pula Kepuasan Konsumen.

\section{Variabel Reliability/Kehandalan}

Hasil pengujian diperoleh nilai $\mathrm{t}$ untuk variabel kehandalan menunjukkan nilai $\mathrm{t}=2,249$ dengan nilai signifikansi sebesar $\backslash 0,052<0,05$. Dengan nilai signifikan si dibawah 0,05 tersebut menunjukkan bahwa Reliability/kehandalan memiliki pengaruh yang signifika nterhada pKepuasan Konsumen.Halini berarti Hipotesis1diterima.Arah diterima. Arah koefisien regresi positif berarti bahwa kehandalan memiliki pengaruh positif yang signifikan terhadap Kepuasan Konsumen.Semakin besar variabel Reliability/ kehandalan yang diberikan Balaputra Barbershop Palembang akan semakin tinggi pula Kepuasan Konsumen,sebaliknyasemakin rendah kehandala ang diberikan maka semakin rendah pula kepuasan konsumen

3. Variabel Responsiveness/Daya
Tanggap

Hasil pengujian diperoleh nilai $t$ untuk variabel daya tanggap menunjukkan nilait $=2,114$ dengan nilai signifikan sisebesar $0,023<0,05$. Dengan nilai signifikansi dibawah 0,05 tersebut menunjukkan bahwa daya tanggap memilik ipengaruh yang signifikan terhadap Kepuasan Konsumen. Hal ini berarti Hipotesis1diterima.Arah diterima. Arah koefisien regresi positif berarti bahwa daya tanggap memiliki pengaruh positif yang signifikan terhadap Kepuasan Konsumen.Semakin besar variabel daya tanggap yang diberikan Balaputra Barbershop Palembang akansemakin tinggi kepuasan konsumen, sebaliknya semakin rendah daya tanggap yang diberikan perusahaan semakin rendah pula kepuasan konsumen.

\section{Variabel Assurance/Jaminan}

Hasil pengujian diperoleh nilai $\mathrm{t}$ untuk variabel jaminan menunjukkan nilai $\quad=2,256$ dengan nilai signifikans isebesa $\mathrm{r} 0,000<0,05$. Dengan nilai signifikansi dibawah 0,05 tersebu tmenunjukkan bahwa jaminan memiliki pengaruh yang signifikan terhadap Kepuasan Konsumen.Ha lini berarti Hipotesis 1 diterima. Arah diterima. Arah koefisien regresi positif berarti bahwa jaminan memiliki pengaruh positif yang signifikan terhadap Kepuasan Konsumen. Semakin besar variabel jaminan yang diberikan perusahaan akan semakin tinggip ula Kepuasan Konsumen,sebaliknya semakin rendah jaminan yang diberikan perusahaan semakin rendah pula Kepuasan Konsumen.

\section{VariabelEmpathy/kepedulian}

Hasil pengujian diperoleh nilai $\mathrm{t}$ untuk variabel kepedulian (empathy) menunjukkan nilai $\mathrm{t}=3,195$ dengan nilai signifikansi sebesar $0,027<0,05$. Dengan nilai signifikansi di bawah 0,05 tersebut menunjukkan bahwa kepedulian (empathy) memiliki pengaruh yang signifikan terhadap Kepuasan Konsumen. Hal ini berarti Hipotesis 5 diterima. Arah koefisien 
regresi positif berarti bahwa empati memiliki pengaruh positif yang signifikan terhadap Kepuasan Konsumen. Semakin besar kepedulian (emphaty) yang diberikan Balaputra Barbershop Palembangakan semakin tinggi pula Kepuasan Konsumen ,sebaliknya semakin rendah kepedulian (emphaty) yang diberikan perusahaan semakin rendahp ula Kepuasan Konsumen.

\subsubsection{Uji f (Pengujian hipotesis secara simultan)}

Hasil perhitungan regresi secara simultan (bersama-sama) dapat dilihat padaTabel4.29berikut :

Tabel 4.29

Hasil Analisis Secara Simultan

ANOVA ${ }^{b}$

\begin{tabular}{|l|r|r|r|r|r|}
\hline Model & \multicolumn{1}{|l|}{$\begin{array}{l}\text { Sumof } \\
\text { Squares }\end{array}$} & df & MeanSquare & F & Sig. \\
\hline 1 Regression & 14.087 & 5 & 4.696 & 33.793 & $.000^{\mathrm{a}}$ \\
Residual & 13.340 & 94 & .139 & & \\
Total & 27.427 & 99 & & & \\
\hline
\end{tabular}

a.Predictors:(Constant),tangibles, reliability,responsiveness,assurance,empathy

b.DependentVariable:kepuasan konsumen

Pengujian pengaruh variabel bebas secara bersama-sama terhadap variabel terikatnya dilakukan dengan menggunakan uji F. Hasil perhitungan statistikmenunjukkannilaiF hitung $=33,793$ dengansignifikansisebesar $0,000<0,05$. Dengan nilai signifikansi dibawah 0,05 menunjukkan bahwa secara bersama-samabukti fisik, keandalan, daya tanggap, jaminan dan kepedulian mempunyai pengaruh yang positi dan signifikan terhadap kepuasan konsumen.

\subsubsection{Koefisien Determinasi}

Koefisien determinasi ini digunakan untuk mengetahui seberapa besar pengaruh variabel-variabel bebas memiliki pengaruh terhadap variabel terikatnya. Nilai koefisien determinasi ditentukan dengan nilai adjusted $R$ square

Tabel 4.30

Koefisien Determinasi

ModelSummary ${ }^{b}$

\begin{tabular}{|l|r|r|r|r|}
\hline Model & \multicolumn{1}{|c|}{$\mathrm{R}$} & RSquare & $\begin{array}{c}\text { AdjustedR } \\
\text { Square }\end{array}$ & $\begin{array}{l}\text { Std.Errorof } \\
\text { theEstimate }\end{array}$ \\
\hline 1 & $.717^{\mathrm{a}}$ & .514 & .498 & .37277 \\
\hline
\end{tabular}

a. Predictors:(Constant),tangibles, reliability,responsiveness, assurance,empathy

b.DependentVariable:kepuasan konsumen

Hasil perhitungan regresi dapat diketahui bahw akoefisien determinasi (adjusted ${ }^{2}$ ) yang diperoleh sebesar0,514.Hal ini berarti $51,4 \%$ kepuasan konsumen dipengaruhi oleh tangibles, reliability, responsiveness, assurance, empathy, sedangkan sisanya yaitu 48,6\% kepuasan konsumen 
dipengaruhi oleh variabel-variabel lainnya yang tidak diteliti dalam penelitian ini.

\subsection{PEMBAHASAN}

Secara umum penelitian ini menunjukkan hasil yang cukup memuaskan. Hasil analisis deskriptif menunjukkan bahwa kualitas pelayanan yang diberikan oleh Balaputra Barbershop Palembang secara umum sudah menunjukkan indikator yang cukup baik.Hal inidapat ditunjukkan dari banyaknya tanggapan kepuasan yang tinggi dari responden terhadap kondisi dari masing-masing variabel penelitian. Dari hasil tersebut selanjutnya diperoleh bahwa variabel kualitas pelayanan dalam kelima dimensinya memiliki pengaruh yang positif dan signifikan terhadap kepuasan konsumen. Hal ini dikarenakan bahwa dengan pemberian pelayanan yang berkualitas,maka hal tersebut akan memberikan kepuasan dalam diri konsumen sehingga mendorong terciptanya kepuasan konsumen.

Hasil penelitian menunjukkan bahwa variabel tampilan fisik / tangibles memiliki pengaruh yang positif dan signifikan terhadap kepuasan. Hasil ini memberikan bukti empiris bahwa bukti fisik dari pelayanan yang diberkandengan memberikan ruang tunggu yang nyaman serta menjaga areal pemotongan rambut untu selalu terjamin kebersihannya.

Hasil penelitian menunjukkan bahwa variabel kehandalan /reability memiliki pengaruh yang positif dan signifikan terhadap kepuasan konsumen. Kemudian hasil penelitian ini juga memberikan bukti empiris bahwa kehandalan dari pihak Balaputra Barbershop Palembang yang ditunjukkan dengan kehandalandalam bentuk prosedur menanggapi keluhan, kesediaan karyawan utuk berkonsultasi dan memberikan solusi serta pelayanan yang memuaskan jugaakan dipertimbangkan dalam membentuk kepuasan konsumen.

Hasil penelitian menunjukkan bahwa variabel daya tanggap
Iresponsiveness memiliki pengaruh yang positif dan signifikan terhadap kepuasan konsumen .Hasil ini memberikan bukti empiris bahwa daya tanggap dari perusahaan yang ditunjukkan dengan kecepatan dalam menanggapi keluhan, tanggapan terhadap pertanyaanpertanyaan konsumen serta memberikan solusi terhadap setiap permasalahan konsumen juga dengan cepat akan memberikan pengaruh dalam terbentuknya kepuasan konsumen.

Hasil penelitian menunjukkan bahwa variabel assurancel jaminan memiliki pengaruh yang positif dans ignifikan terhadap kepuasan konsumen Hasil ini memberikan bukti empirisbahwa jaminan dari Balaputra Barbershop Palembang akan memberikan peningkatan pada kepuasan konsumen.Halini ditunjukkan dengan profesionalisme dalam melayan ikonsumen,serta keramahan yang diberikan akan memberikan kesanyang lebih baik pada konsumen sehingga meningkatkan kepuasan bagi konsumen.

Hasil penelitian terakhir untuk variabel empathy / kepedulian memiliki pengaruh yang positif dan signifikan terhadap loyalitas.Hasil ini memberikan bukti empiris bahwa empati dari Balaputra Barbershop Palembang akan memberikan peningkatan pada kepuasan konsumen. Hal ini ditunjukkan dengan memberikan pelayanan dan komunikasi yang sama kepada semua konsumen tanpa terkecuali.

\section{Penutup}

A. Kesimpulan

Berdasarkan uraian yang telah dipaparkan terhadap data penelitian yang telah dianalisis, maka kesimpulan yang dapat ditarik dalam skripsi kali ini, adalah sebagai berikut :

1. Variabel kualitas pelayanan secara bersama-sama berpengaruh secara signifikan dan positif terhadap Kepuasan Konsumen Balaputra Barbershop Palembang . Hal ini dibuktikan dengan hasil perhitungan SPSS yang menyatakan bahwa fhitung $>$ ftabel sehingga dari keseluruhan variabel yang digunakan 
dalam penelitian ini $\mathrm{H}_{\mathrm{O}}$ ditolak

2. Sedangkan dalam hal besarnya pengaruh variabel Kualitas Pelayanan secara keseluruhan dapat dilihat dari koefisien regresi masingmasing, yaitu sebesar 0,514. Jadi dengan demikian dapat disimpulkan bahwa variabel kualitas pelayanan mempunyai pengaruh sebesar 51,4 $\%$ terhadap Kepuasan Konsumen.

3. Berdasarkan hasil perhitungan diatas, dapat dikatakan bahwa variabel Kualitas Pelayanan memiliki pengaruh signifikan positif terhadap Kepuasan Konsumen. Maka dengan demikian, dengan selalu meningkatkan dan melakukan perbaikan terhadap kualitas pelayanan dari segi bukti fisik, kehandalan, daya tanggap, jaminan, serta kepedulian maka hal tersebut dapat lebih meingkatkan kepuasan konsumen.

\section{B. Saran}

Berdasarkankesimpulandarihasil penelitian,maka diajukanbeberapasaran yaitu sebagai berikut:

1. Kualitas pelayanan yang telah dilakukan Balaputra Barbershop Palembang selama ini harus tetap dipertahankan bahkan harus lebih ditingkatkan lagi. Hal ini dikarenakan berdasarkan hasil penelitian yang telah dilakukan bahwa kualitas pelayanan memiliki pengaruh yang signifikan terhadap kepuasan konsumen.

2. Pihak Balaputra Barbershop Palembang agar selalu memperhatikan setiap aspek kualitas pelayanan yang terdiri dari bukti fisik, kehandalan, daya tanggap, jaminan dan kepedulian. Dengan selalu menjaga hubungan dan komunikasi yang baik dengan setiap konsumen

3. Guna tetap menjaga kualitas pelayanan yang terbaik, maka sumber daya manusia yang dimiliki oleh Balaputra
Barbershop Palembang Palembang senantiasa harus tetap memiliki pengetahuan yang cukup serta memiliki empati yang tinggi terhadap setiap konsumen.

\section{DAFTAR PUSTAKA}

A.Parasuraman., V.A. Zeithhaml, \& LL. Berry, 2006, "The Behavioral Consequences

Multiple Item Scale for
Measuring Customer Perseption
of Service Quality, Journal of
Retailing, Vol 64
- 2005, "A Conceptual Model of SQ and Its Implications for Future Research," in: Journal of Marketing, pp. $41-50$

Garvin, D. A. (2007). Managing Quality. New York: The Free Press.

Gaspersz, Vincent. 2004. Production Planning and Inventory Control. PT Gramedia Pustaka Umum. Jakarta

Kotler, Philip (2005). Manajemen Pemasaran, diterjemahkan oleh Benyamin Molan. Edisi 11, jilid 1, PT. Indeks Kelompok Gramedia, Jakarta.

Purnama, N. (2006). Manajemen Kualitas Perspektif Global. Edisi 1. Yogyakarta: Ekonisia

Purnama, Nursya'bani; Manajemen Kualitas, Perspektif Global; Ekonisia; 2006; Yogyakarta

Tjiptono, F dan Chandra, G. 2009. Service Quality, Satisfaction, Yogyakarta: Andi.

Widiyanto, Ibnu. 2008. Pointers : Metodologi Penelitian. Semarang: BP Undip, p.126

Yamit, Zulian. (2001) , Manajemen kualitas produk dan jasa, Yogyakarta 